\section{UK electronic engineers call for research-linked tax scheme}

\section{London}

BRITAIN's electronics industry is appealing to the government to reduce corporation tax and introduce a tax-incentive scheme to allow greater investment in research by private industry. Electronics manufacturers are claiming that because of an increasingly competitive world market and the need to show high levels of profit to meet City expectations, funds are being channelled into marketing existing products abroad, resulting in a rationing of research and development expenditure not before seen in this decade.

In the past, such requests for tax incentives have fallen on deaf ears. Last year an Inland Revenue and Treasury study concluded that tax-incentive schemes operating in Britain's main competitor countries produced little benefit. A government white paper (policy document) on civil research and development, published last summer (see Nature 328, 281; 1987), concluded that additional research and development stimulated by tax incentives in the ten countries studied in the survey was roughly one-half of the revenue forgone by the Treasury, "so that the average cost-effectiveness is low".

The Electronic Engineering Association, however, believes that the earlier study neglected to examine in sufficient detail the long-term advantages of the resulting increased investment in research. The association is reiterating the argument for tax incentives in a 20-page document submitted to the government last week advising on ways to promote industrial growth*.

The association, which represents more than 60 companies whose combined annual turnover exceeds $£ 24,000$ million, wants to see corporation tax reduced from 35 per cent to 23 per cent, with the resulting savings to the company used "at least partly" to stimulate investment in research, "rather than solely to increase dividends". The association proposes a concomitant tax allowance of 150 per cent on research and development revenue and capital expenditure, instead of the present 100 per cent. Such a move, it claims, would enable research and development investment to increase by 13 per cent each year and, on the basis of increased sales and the reduction of the imbalance in trade (currently running at a $£ 12,000$ million deficit), it would take only three or four years to compensate the government for the lost tax revenue. The association believes that it would be relatively simple for the government to ensure that tax savings were being invested in research.

The government has persistently implored industry to invest more of its

own money in research and not depend on state funds. It cites figures from the Organisation for Economic Cooperation and Development showing that less than 66 per cent of total research and development carried out by British industry in 1985 was funded from industry's own pocket, compared with 67 per cent in the United States, 72 per cent in France (in 1984), 76 per cent in Italy, 82 per cent in West Germany and 98 per cent in Japan.

\section{London}

BRITAIN's academic engineers are being asked to consider ways of restructuring engineering education to cope with rapidly changing technology and increasing financial strain. The call comes from the Engineering Council, the profession's supervisory body, in what is seen as an attempt to persuade the engineers themselves to determine their own fate, rather than have it imposed upon them during the expected restructuring of the academic science base.

The council is circulating a discussion document suggesting ways of concentrating resources. The council says changes are needed in order to solve "difficulties of a character and scale not previously encountered" by engineering education. "This situation arises from the rapidly changing technical scene, having profound implications for academic courses, against a background of human and capital resource pressures which strain the system in many ways and at many points."

In passing, the council says it does not support the suggestion of the Advisory Board for the Research Councils (ABRC), that institutions be graded depending on their mix of research and teaching.

At present, engineering education is spread between 45 universities, 35 polytechnics and central institutions and a number of institutes of higher education and colleges of technology, providing a total of 630 accredited degree courses in engineering. In 1986, 19,000 undergraduates embarked on degree courses in engineering (including about 2,000 women; the Engineering Council is campaigning to attract more women into the profession); 15,000 engineering graduates are produced annually. Additionally, around 3,800 graduates study taught masters courses, and at any one time about 5,100 students are working for research degrees across all fields of engineering.

The document takes to task academic staff for operating in a "relatively narrow

\title{
Proposals to engineer change in British higher education
}

The electronics companies say that of the total civil industry spending on research and development in 1985 of $£ 5,146$ million, their industry spent $£ 1,738$ million, threequarters of which was privately funded.

The association says that electronics manufacturers are in good spirit and expect to meet targets at a level they can afford. That level, however, while acceptable to individual companies, "is not enough to stop and reverse an ever-widening trade gap in electronics products, particularly in computers and components".

Simon Hadlington

Industrial Growth, Electronic Engineering Association, London.

field and seldom find themselves in a team of like specialists numbering more than three or four. Often they plough a lone furrow." The council believes that small departments in which academics work in small, specialized teams "can be very inefficient or lacking in vitality".

One of the main concerns is the increasing difficulty of departments in replacing expensive equipment, to remain representative of modern industry. But the document points out that existing specialized laboratories and equipment are under-used and that "given a finite total resource there are strong arguments for locating at least major equipment installations in a smaller number of centres than exist at present".

The council proposes three 'modes' for restructuring of degree course teaching, emphasizing that an increase in student numbers remains a priority. The details of each mode have been left deliberately vague in an attempt to achieve a high degree of consensus among the council's constituents, and to avoid provoking the level of alarm that was engendered by the ABRC's document.

'Mode A' proposes a straight reduction in the number of centres offering engineering higher education, achieved by mergers or closures, with concomitant expansion of the remaining centres.

'Mode B' would retain the existing number of centres but reduce the number offering honours degree courses.

'Mode C' would develop a limited number of centres of specialism in certain fields, regardless of the actual number of centres offering engineering education.

The Engineering Council itself seems to favour Mode A; it is likely that the remaining two options, if adopted, would eventually evolve into a network of fewer but larger centres - that is, Mode A.

\section{Simon Hadlington}

${ }^{*}$ Restructuring of Engineering Higher Education. (The Engineering Council, London.) 